\title{
サイズ選別された機能ナノクラスターの ソフトランディング
}

\author{
中 嶋敦 ${ }^{1,2}$ \\ 1慶應義塾大学理工学部 函 223-8522 神奈川県横浜市港北区日吉 3-14-1 \\ ${ }^{2}$ JST-ERATO 齿 213-0012 神奈川県川崎市高津区坂戸 3-2-1
}

(2010 年 8 月 17 日受理)

\section{Soft-landing Experiments of Size-selected Functional Nanoclusters}

\author{
Atsushi NAKAJIMA ${ }^{1,2}$ \\ ${ }^{1}$ Keio University, Yokohama, Kanagawa 223-8522 \\ ${ }^{2}$ JST-ERATO, Kawasaki, Kanagawa 213-0012
}

(Received August 17, 2010)

\begin{abstract}
Organometallic sandwich clusters of $\mathrm{M}$ (benzene $)_{2}(\mathrm{M}=\mathrm{V}$ and $\mathrm{Cr}$ ) synthesized in gas phase reaction are soft-landed onto a self-assembled monolayer of $n$-alkanethiol (C4-C22 SAM) at a collision energy of $10-20 \mathrm{eV}$. The resulting adsorption states and thermal desorption kinetics of the soft-landed clusters are studied with infrared reflection absorption spectroscopy and temperature-programmed desorption. The clusters keep their native sandwich structure intact on the SAM substrate. The soft-landed cluster are oriented with their molecular axes largely tilted off the surface normal of the SAM substrate, and exhibit unusually large desorption activation energies $\left(E_{\mathrm{d}}=\sim 130 \mathrm{~kJ} / \mathrm{mol}\right)$. The desorption of the embedded clusters in the SAM is suppressed to around room temperature, and may be associated with the crystal-rotator phase transitions of the SAM matrix.
\end{abstract}

KEYWORDS : soft-landing, organometallic clusters, self-assembled monolayer

\section{1.は じめに}

原子が数個から数千個程度凝集してできたナノメート ル $(\mathrm{nm})$ オーダーの直径のクラスター（以下では，ナ ノクラスター）は，バルク固体に比較すると, 二つの大 きな特徵をもつ。一つは構造上の特徵で, 内部原子に比 べて表面原子の割合が大きい点であり，もう一つは電子 状態の特徵で, 電子準位間隔が広がり室温程度での熱と 競合する点である。このため, ナノクラスターは, 高い 表面活性を有するとともに新奇な合金形成が可能とな り, また, 電子スピン状態を含む新たな電子物性の発現 などが誘起される。したがって，ナノクラスターでは， 構成する総原子数のわずかな差異によって構造や電子物 性が先鋭化して変化する。その上, 複数の元素を混合さ

E-mail : nakajima@chem.keio.ac.jp
せた複合ナノクラスターでは, 総原子数とともに混合比 をパラメーターとして多様な物性が発現するため, 新奇 な機能性を発現する物質単位として位置づけられる。実 際, 近年では高機能電子材料や高選択的光触媒の創成を 可能にする新しい物質系として, 複合ナノクラスターが 注目を集めている。本稿では, 複合クラスターの機能性 とその表面修飾の視点から, 複合クラスターを物質単位 とする表面科学の新展開を, ナノクラスターを非破壊蒸 着するソフトランディング法の有用性とともに紹介する。

\section{2. 気相ナノクラスターの特徵}

ナノクラスターは, 孤立状態の原子 - 分子の気相と, 液体・固体の凝集相（バルク）との「中間相」として考 えられ, 溶液や固体中における様々な構造, 電子状態, 反応を, 微視的に理解するための基礎科学上のモデルと して位置づけられる。1980 年代以降, レーザー蒸発法, 
イオンスパッタリング法などの生成法の開発によって, 気相中において原子や分子のナノクラスターが容易に生 成できるようになった。そして，ナノクラスターの物性 を構成原子数を精密に区別した研究が進められ，正 20 面体構造や電子殼構造などの新しい構造や物性が明らか にされてきた。さらに, 気相反応場からフラーレンやカ 一ボンナノチューブをはじめとする様々な新物質が生み 出されてきたことは周知の事実であるが，最近では遷移 金属原子と有機分子とを複合化した 1 次元多層有機金属 ナノクラスターや，ケージ構造をもつシリコン複合クラ スターなどが新たに生成され, 一次元伝導体や光磁気機 能材料としての可能性が気相中の研究から具体的に示さ れている1,2)。

発光特性, 磁気特性, エネルギー変換特性といった機 能を発現する基本単位は, $1-5 \mathrm{~nm}$ 前後の物質, すなわ ち原子や分子が数個から千個凝集したナノ構造体である ことを踏まえると, 気相中で次々と生み出される「機能」 ナノクラスターをサイズ・組成等を選択しながら機能性 材料へ組み上げる方法論は, 真のボトムアップ材料創成 ならびに表面修飾技術と捉えることができる。この実現 のためには, 気相中で生成したナノクラスターを，質量 選別しながら，その構造を壊すことなく固体表面上に担 持させる必要がある。また, 基板蒸着されたナノクラス ターの固定化では, 配向や周期構造を含めて, 制御性よ く表面ナノ構造を構築する方法論の確立が重要である。

\section{3. 一次元有機金属ナノクラスターの生成}

一般に有機金属錯体の化学合成は, 不活性ガス雲囲気 下の溶媒中で行われる。さらに溶媒も取り除いて真空中 における気相反応を利用すると, 溶媒などの周囲の環境 因子のない条件下で, 反応単位の金属原子と有機配位子 とを直接に反応させることができる。この「気相反応 場」では，励起状態の失活やエネルギー散逸が抑制され るため, 反応に関わるエネルギーを局所空間内に集中さ せ，極めて短い時間内に反応を進行，完了させることが できる。

このような気相反応場での物質創成は, 通常の溶液内 の反応では生成しない特異なナノクラスターの生成を可 能とする。また, 真空下で行われるこの物質創成では, 種々の物理化学的な物性評価の手法の利用が容易である ため, ナノクラスターの電子状態, 光物性, 磁性などを 詳細に解明できる。以下では, この気相反応場を用いて 生成されるナノクラスターの例として, 多層サンドイッ チ構造を有する有機金属ナノクラスターについて紹介する。

真空装置内でレーザー蒸発法を用いて遷移金属蒸気を 発生させ, さらに有機配位子としてベンゼン $\left(\mathrm{C}_{6} \mathrm{H}_{6}\right)$ 分

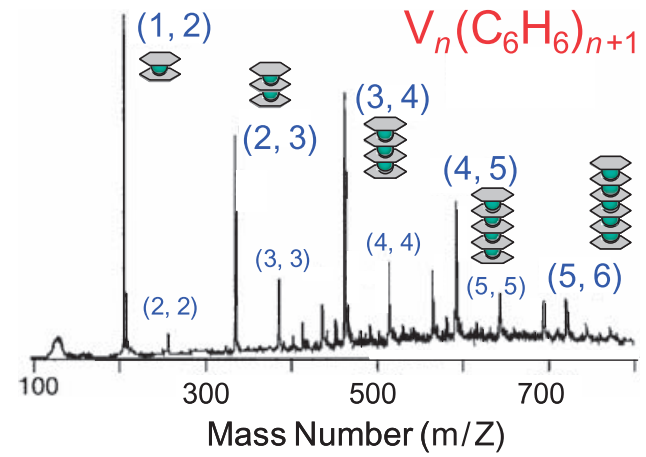

Fig. 1. (color online). Mass spectrum for V-benzene $\left(\mathrm{C}_{6} \mathrm{H}_{6}\right)$ clusters.

子の蒸気を反応させると, 構成単位同士の効率的な気相 反応によって, Fig.1のような光イオン化質量スペクト ルが得られる。特異的に生成されるバナジウム金属の有 機金属ナノクラスターは, ベンゼン分子の数がバナジウ 厶原子の数よりも 1 分子多く, $\mathrm{V}_{n}\left(\mathrm{C}_{6} \mathrm{H}_{6}\right)_{n+1}$ の一定組成 をもつ。この組成の構造は, 化学吸着害験 ${ }^{1}$, イオン移 動度 ${ }^{3)}$ による研究から, $\mathrm{V}$ 原子と $\mathrm{C}_{6} \mathrm{H}_{6}$ 分子が交互に重 なった多層サンドイッチ構造（Fig. 1 の構造）であるこ とがわかった。また，この $\mathrm{V}_{-} \mathrm{C}_{6} \mathrm{H}_{6}$ ナノクラスターのイ オン化エネルギーを測定すると, その值は多層構造の成 長につれて急激に低下し，例えば，1 層から 4 層まで変 化すると， $6 \mathrm{eV}$ から $4 \mathrm{eV}$ 以下に低下することがわかっ た。これは, $\mathrm{V}$ 原子の $\mathrm{d}$ 電子が, $\mathrm{C}_{6} \mathrm{H}_{6}$ 分子の $\pi$ 軌道を 介して分子軸方向に非局在化して擬似バンドを形成する ためで ${ }^{4)} \mathrm{V}^{-} \mathrm{C}_{6} \mathrm{H}_{6}$ ナノクラスターは, 層の増加に伴っ て光吸収が段階的に長波長シフトする。

また, この $\mathrm{V}_{-} \mathrm{C}_{6} \mathrm{H}_{6}$ ナノクラスターの電子スピンが, 強磁性的配列を示すことが見出された。V-C $\mathrm{C}_{6} \mathrm{H}_{6}$ ナノク ラスターでは, 前述の分子軸に沿って非局在化する $\mathrm{d}$ 電 子とは別に, 各 $\mathrm{V}$ 原子上に孤立した $\mathrm{d}$ 電子が 1 個ずつ 存在する。この $\mathrm{d}$ 電子のスピン配列を, シュテルン・ゲ ルラッハ型磁場偏向測定によって調べたところ, 各 $\mathrm{V}$ 原子上の電子スピンは強磁性的な配列をすることが明ら かになった5)。電子物性のこれらの特徵は，この多層サ ンドイッチ構造をとる $\mathrm{V}^{-} \mathrm{C}_{6} \mathrm{H}_{6}$ ナノクラスターが, 波長 選択的な光応答とともに分子磁石の単位であることを示 しており，光を用いた磁気スイッチングの機能単位とし ての可能性を示している。

\section{4. ナノクラスターのソフトランディング法}

上記のようなナノクラスターの種々の物性を利用し て, 特定のサイズ・組成のナノクラスターが有する機能 を活かした材料創製を実現させるためには，ナノクラス 
ターをサイズ選別して大量に集積することが必要であ る。さらに, 機能表面の作製では, 単にサイズ・組成を 選別するばかりでなく, 構造と電子状態を保持してナノ クラスターを表面に固定化することが求められる。そこ で，以下に述べるようなソフトランディング技術を Fig. 2 に示す装置として開発した6)。

一般に, 質量分析をする際には, ナノクラスターイオ ンは数十 $\mathrm{eV}$ 以上の運動エネルギーをもっており, その まま蒸着させるとナノクラスターが壊れてしまう。一 方，イオンの運動エネルギーを小さくすれば，空間電荷 効果によりイオンビームが発散してしまい, 十分な量の イオンを基板上に蒸着することが難しくなる。この解決 手法として, アルカンチオール分子の自己組織化単分子 膜（Self-Assembled Monolayer : SAM）の利用を提案した (Fig. 2 挿入図 $)^{6 \sim 10)}$ 。アルカンチオール分子の SAM 膜程 度の厚みを有する薄膜上では, 金属基板からナノクラス ターイオンに電子が供与されるので, 蒸着された正イオ ンは速やかに中性化され基板上に降着する。さらに，ナ ノクラスターによる機能表面を実現するには, 基板上で のナノクラスターの配向や二次元配列といった吸着状態 を制御することが重要である。SAM 膜では, 構成する 分子鎖末端を様々に化学修飾できるので，適切な官能基 等の導入によって, ナノクラスターと膜末端との間に生 じる分子間相互作用をデザインできる特徴をもつ。

さて, レーザー蒸発法によって生成させたバナジウ ムーベンゼン $1: 2$ ナノクラスター $\mathrm{V}\left(\mathrm{C}_{6} \mathrm{H}_{6}\right)_{2}$ をアルカン チオール SAM 上にソフトランディングをした。基板上 に蒸着されたナノクラスターの構造と吸着状態は, 赤外 反射吸収分光法 (Infrared Reflection Absorption Spectroscopy : IRAS）などの分光学的手段から定量的に評価し た。基板には, 金（111）基板表面上に作成したへキサ デカンチオール $\left(\mathrm{C} 16: \mathrm{CH}_{3}\left(\mathrm{CH}_{2}\right)_{15} \mathrm{SH}\right)$ の SAM (C16SAM）を使用した。SAM 基板の作成では，金基板をピ

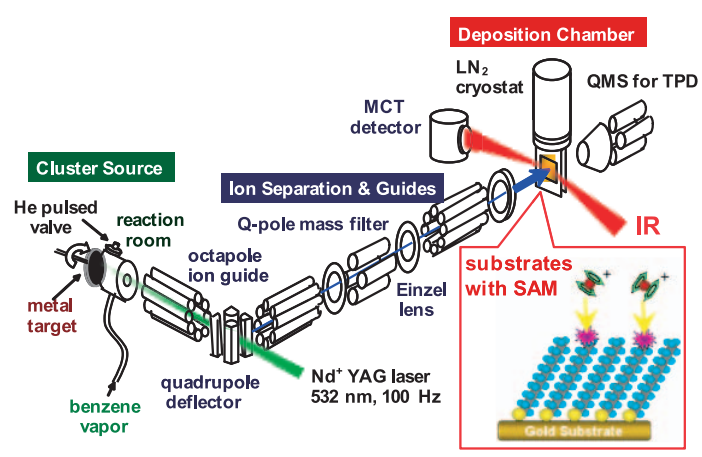

Fig. 2. (color online). Apparatus for soft-landing experiment toward SAM.
ラン八溶液（濃硫酸：過酸化水素 $=3: 1$ の混合溶液） に浸漬させて化学的に表面を研磨した後, C16 エ夕ノー ル溶液 $(2 \mathrm{mM})$ 中に, 24 時間振とうさせながら浸漬さ せ, 洗浄後に超高真空槽に導入して基板温度約 $70^{\circ} \mathrm{C} て ゙$, 10 時間ほどアニーリング (annealing) する。基板上に C16-SAM が形成したことは, サイクリックボルタンメ トリー (Cyclic Voltammetry:CV) 法や IRAS 法によっ て確認した。

\section{1 ナノクラスターの分光測定}

$\mathrm{V}\left(\mathrm{C}_{6} \mathrm{H}_{6}\right)_{2}$ の正イオン : $\mathrm{V}\left(\mathrm{C}_{6} \mathrm{H}_{6}\right)_{2}{ }^{+}$を, C16-SAM 基板 の上に蒸着したところ, Fig. 3 のような赤外吸収スペク トル (700-1000 cm $\left.{ }^{-1}\right)$ を観測した。ナノクラスターの 蒸着量は, クラスター正イオンが金属基板で中性化する 際に流れるトンネル電流から求められる。この波数領域 には, 中性状態の $\mathrm{V}\left(\mathrm{C}_{6} \mathrm{H}_{6}\right)_{2}$ の振動に由来した 3 本の吸 収ピークが観測される。最も低波数側 $\left(740-750 \mathrm{~cm}^{-1}\right)$ に観測されるバンドは， $\mathrm{C}_{6} \mathrm{H}_{6}$ 分子の $\mathrm{CH}$ 基が同位相で 面外変角振動するモードであり, $956 \mathrm{~cm}^{-1}$ のバンドは 二つの $\mathrm{C}_{6} \mathrm{H}_{6}$ 分子の炭素骨格が逆位相で振動するモード である。この二つの振動モードでは $\mathrm{V}\left(\mathrm{C}_{6} \mathrm{H}_{6}\right)_{2}$ の主軸方 向（Fig. 3 扱入図）に遷移双極子モーメントが発生す る。一方, 最も高波数側の $986 \mathrm{~cm}^{-1}$ に観測されている バンドは, $\mathrm{C}_{6} \mathrm{H}_{6}$ 分子の $\mathrm{CH}$ 基が面内に扔いて同位相で 変角振動する二重縮重モードである。この振動モードは $\mathrm{V}\left(\mathrm{C}_{6} \mathrm{H}_{6}\right)_{2}$ の主軸に対して垂直方向にその遷移双極子モ ーメントをもつので, $\mathrm{V}\left(\mathrm{C}_{6} \mathrm{H}_{6}\right)_{2}$ の主軸が基板表面に対 して平行に近くなるほど強く観測される。ここで, IRAS の表面選択律から, 遷移双極子モーメントが基板 表面の法線方向と平行に近いほど, その赤外吸収が強く 観測されるので, これらの振動モードの強度比から, 基 板上での $\mathrm{V}\left(\mathrm{C}_{6} \mathrm{H}_{6}\right)_{2}$ の配向を知ることができる。

$\mathrm{Ar}$ マトリックス中での無配向の $\mathrm{V}\left(\mathrm{C}_{6} \mathrm{H}_{6}\right)_{2}$ によって得 られる赤外吸収スペクトルに観測されるピーク強度比と 比べると，C16-SAM 基板の場合では，747, $956 \mathrm{~cm}^{-1}$

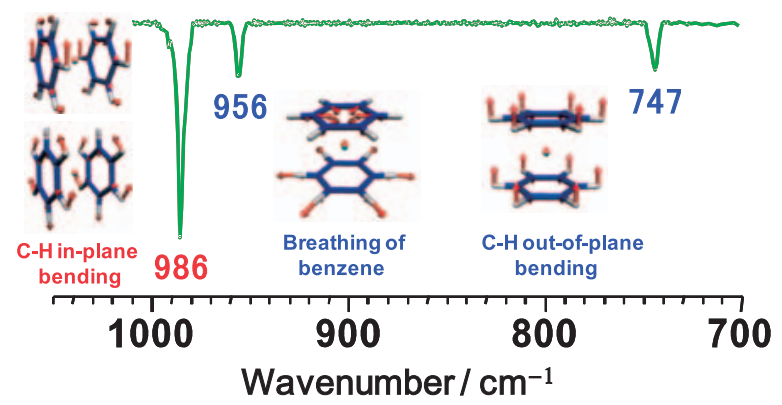

Fig. 3. (color online). IR spectrum for $\mathrm{V}\left(\mathrm{C}_{6} \mathrm{H}_{6}\right)_{2}$ cluster and assignments. 
のピークに比べて, $986 \mathrm{~cm}^{-1}$ のピークが非常に強く観 測された。これは前述の表面選択律から，C16-SAM 基 板上の $\mathrm{V}\left(\mathrm{C}_{6} \mathrm{H}_{6}\right)_{2}$ は, その主軸を基板表面とほほ平行に して，配向が揃った状態で吸着していることを示してい る。ピークの強度比から, C16-SAM 上の V $\left(\mathrm{C}_{6} \mathrm{H}_{6}\right)_{2}$ は その主軸が基板の法線方向から約 80 度傾いて吸着して いることがわかった ${ }^{6)}$ 。この配向挙動は, $\mathrm{V}\left(\mathrm{C}_{6} \mathrm{H}_{6}\right)_{2}$ が SAM の分子鎖中に侵入することにより, Fig. 4のよう に生じていると考えられる。実際, SAM の分子の炭化 水素鎖の水素原子をすべてフッ素原子に置換したとこ ろ, この配向角は大きく変化することがわかった7)。こ れは, 炭素鎖の周囲の局所的な相互作用によって, $\mathrm{V}\left(\mathrm{C}_{6} \mathrm{H}_{6}\right)_{2}$ が配向が決定されることを示しており，SAM の化学修飾によってナノクラスターの配向を制御できる ことを示唆している。

\section{2 ナノクラスターの基板上での挙動}

本節では, C16 のアルカンチオールの炭素鎖長を C4 まで短く，もしくはC22 まで長くした場合，どのよう な熱力学的安定性や脱離過程になるかを述べる。Fig. 5

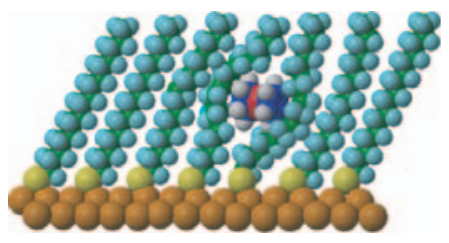

Fig. 4. (color online). Schematic image for $\mathrm{V}\left(\mathrm{C}_{6} \mathrm{H}_{6}\right)_{2}$ cluster inside SAM.
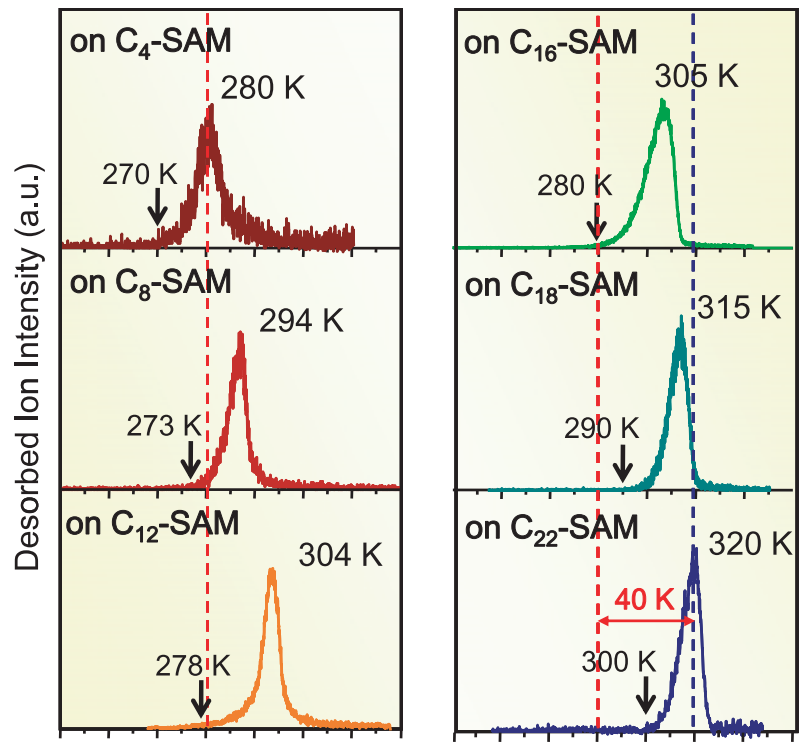

220240260280300320340360220240260280300320340360 Substrate Temperature (K)

Fig. 5. (color online). TPD spectra for $\mathrm{V}\left(\mathrm{C}_{6} \mathrm{H}_{6}\right)_{2}$ from C4C22 SAM.
にはソフトランディングした $\mathrm{V}\left(\mathrm{C}_{6} \mathrm{H}_{6}\right)_{2}$ （蒸着量 : $4 \times$ $10^{13}$ 個）について，基板温度を昇温して得られる昇温脱 離（Temperature Programmed Desorption : TPD）スペクト ルを示した。C16よりも鎖長を短くすると脱離しきい温 度が低温側に，鎖長を長くすると高温側にシフトする。 しきい值付近の挙動から各基板上での $\mathrm{V}\left(\mathrm{C}_{6} \mathrm{H}_{6}\right)_{2}$ 脱離の 活性化エネルギーを求めると, C4-SAM では $58.7 \mathrm{~kJ} /$ $\mathrm{mol}, \mathrm{C} 8 \mathrm{SAM}$ では $60.3 \mathrm{~kJ} / \mathrm{mol}$ で, SAM 修飾前の $\mathrm{Au}(111)$ での $57.6 \mathrm{~kJ} / \mathrm{mol}$ とほぼ同程度であった。これ に対して, C16-SAM では活性化エネルギーが $124 \mathrm{~kJ} /$ mol と増大し, C22-SAM では化学吸着熱に匹敵する值 $(\mathrm{Ed}=\sim 150 \mathrm{~kJ} / \mathrm{mol})$ へと著しく増大していることがわ かった ${ }^{6,8)}$ 。

さらに, TPD スペクトルの形状は, C4 から C22 へと 鎖長が長くなるにつれて対称な形状から徐々に非対称な ピーク形状へと変化した。このピーク形状の変化は，脱 離過程が 2 次脱離（対称ピーク）から 1 次脱離（非対称 ピーク）に変化することを示している。すなわち，C4$\mathrm{SAM}$ の場合には, $\mathrm{V}\left(\mathrm{C}_{6} \mathrm{H}_{6}\right)_{2}$ クラスターは表面に物理吸 着しているだけで，基板温度の上昇とともに基板上で拡 散衝突が起こり，2 次脱離が進行する。一方，ナノクラ スターの大きさに対して鎖長が十分に長い C16 以上に なると, クラスターは蒸着時に SAM 内部に侵入して強 く捕捉され，基板温度が上昇しても拡散することなく直 接脱離 (一次脱離) したものと考えられる。

この様子をさらに確かめるために, $\mathrm{Cr}\left(\mathrm{C}_{6} \mathrm{H}_{6}\right)_{2}$ 錯体を 異なる手法で基板蒸着して, その脱離過程を観測した。 この $\mathrm{Cr}\left(\mathrm{C}_{6} \mathrm{H}_{6}\right)_{2}$ 錯体は, サンドイッチ型 $\mathrm{V}\left(\mathrm{C}_{6} \mathrm{H}_{6}\right)_{2}$ クラ スターの $\mathrm{V}$ 原子を $\mathrm{Cr}$ 原子に置換したもので，化学的安 定性の指標である 18 電子則を満たす安定な錯体分子で ある。このため, 固体試料から中性状態の蒸気を得るこ とが可能である。Fig. 6 （b）に C18-SAM にソフトラン ディング単離された $\mathrm{Cr}\left(\mathrm{C}_{6} \mathrm{H}_{6}\right)_{2}$ の TPD スペクトルを示 す。また比較として, 気相堆積法 (PVD)によって

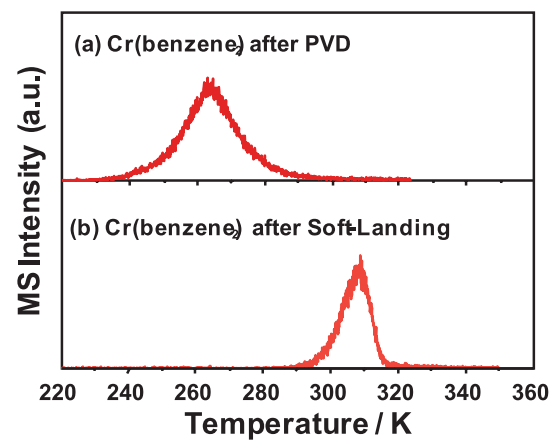

Fig. 6. (color online). Two TPD spectra for $\mathrm{Cr}\left(\mathrm{C}_{6} \mathrm{H}_{6}\right)_{2}$ from C18 SAM. 
$\mathrm{Cr}\left(\mathrm{C}_{6} \mathrm{H}_{6}\right)_{2}$ 錯体の固体試料からの蒸気を熱蒸着（２5 $\mathrm{meV})$ によって C18-SAM へ蒸着させた際の TPD スペク トルも合わせて示した（Fig.6（a）。熱蒸着させたクラ スターの TPD スペクトルは脱離のピーク温度が約 265 $\mathrm{K}$ と室温よりも低い温度で熱脱離が始まり, またブロー ドなピーク形状を示している。このブロードな形状はク ラスターが SAM 表面上で熱拡散を伴いながら脱離して いることを示唆している。一方, ソフトランディング単 離されたクラスターは脱離のピーク温度が $300 \mathrm{~K}$ と高温 側へシフトし，またそのシャープな非対称のピーク形状 から SAM 基板上での熱拡散も抑制されていることがわ かる。この結果から, ソフトランディング法によって単 離されたナノクラスターはSAM マトリックス内部に捕 捉されていることがわかった。

\section{3 ナノクラスターの捕捉メカニズム}

弱い分子間相互作用で, 室温以上まで固体基板上に固 定される原理は, アルキル分子鎖の自己組織化に基づく 秩序化によっている。すなわち, ナノクラスターの SAM 内部での固定化の原理は, 選別されたイオンが, 10-20 eV の並進エネルギーで表面に衝突する際，アル キル分子鎖の秩序構造を局所的に融解状態にしながら自

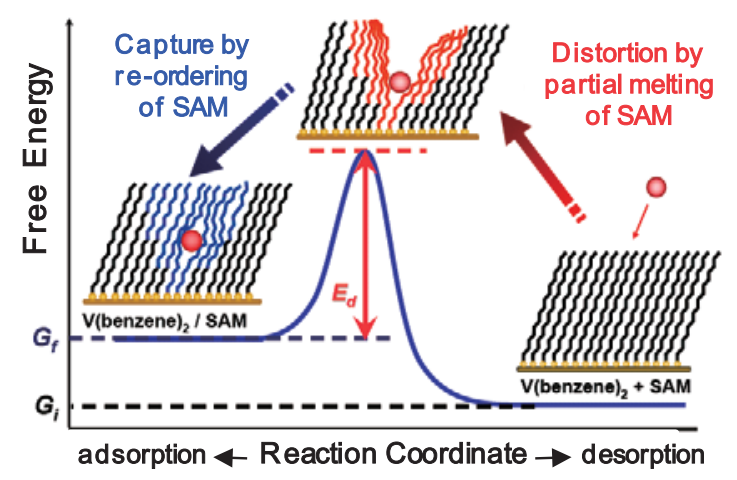

Fig. 7. (color online). Mechanism for the trapping of $\mathrm{M}\left(\mathrm{C}_{6} \mathrm{H}_{6}\right)_{2}$ cluster inside SAM.

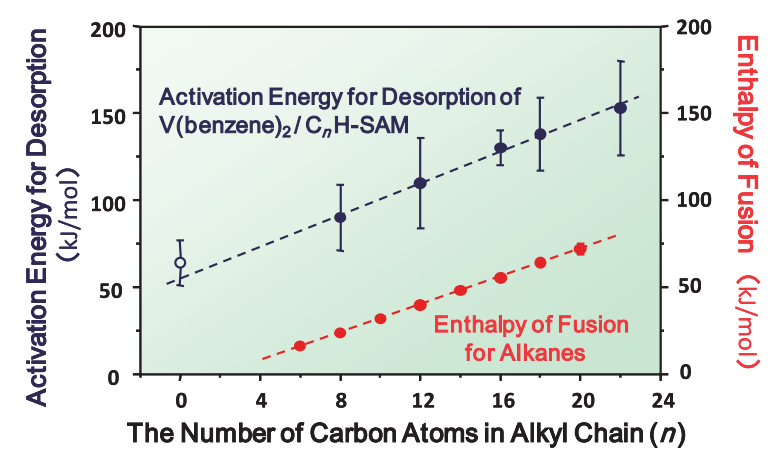

Fig. 8. (color online). Desorption energy of $\mathrm{V}\left(\mathrm{C}_{6} \mathrm{H}_{6}\right)_{2}$ from various SAM.
己組織化単分子膜内部に侵入し, 再び秩序化によって捕 捉される (Fig. 7)。実際, 捕捉したナノクラスターを脱 離させるための活性化エネルギーはアルキル鎖長が長い ほど大きく, また, その鎖長依存性は Fig. 8 に示したよ うにアルキルチオール分子固体の相転移に伴うエンタル ピー変化の鎖長依存性と極めてょく一致しており, クラ スターの脱離が自己組織化単分子膜の 2 次元融解と相関 している ${ }^{8)}$ 。

さらに SAM の 2 次元融解を振動スペクトルの点から 検証した。Fig. 9 は, SAM の振動のうち C-H 反対称伸 縮振動モード $\left(\mathrm{d}^{-}\right)$の積分強度を基板温度に対してプ ロットした結果を示している。眓からわかるように, 振 動ピークの積分強度は 150-250 K の領域と 300-350 K の 領域で, それぞれ単調に変化している。これらの温度領 域はアルカンチオール分子の 3 次元凝集相と対応してお り，150-250 K の低温側は秩序相である crystal 相に, 一 方, 300-350 K の高温領域は, 分子軸周りの回転にゴー シュ（gauche）型のねじれが誘起された rotator 相に対応 している。このことから, アルカンチオール分子が金基 板上に単分子膜として 2 次元化されると, 3 次元凝集相 と同様の crystal-rotator 相転移が起こり，C18-SAM にお ける相転移温度は, 振動ピークの強度の傾きが変化する 290 K であることがわかる。この温度は Fig. 5 で得られ
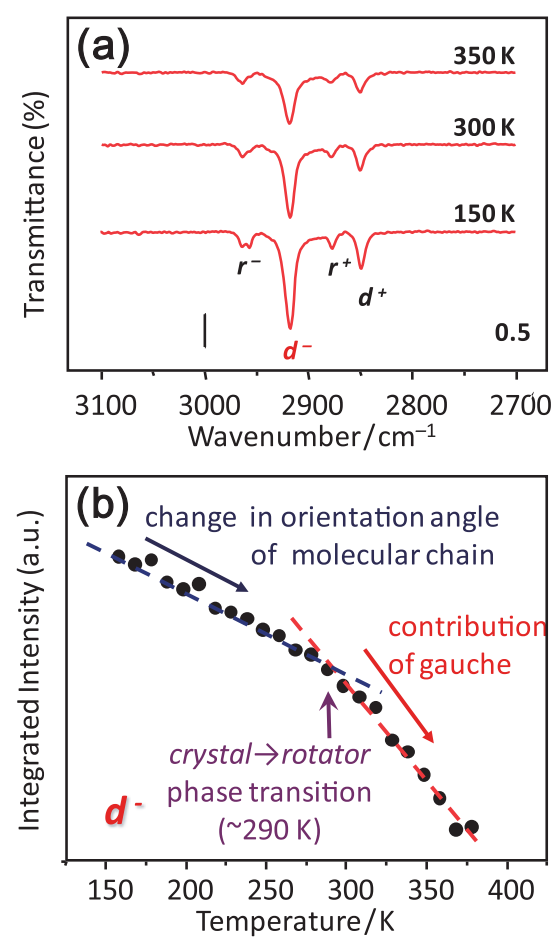

Fig. 9. (color online). IRAS spectra for C18-SAM at 150$350 \mathrm{~K}$ (a), and temperature dependence of $\mathrm{CH}$ antisymmetric vibration (b). 
るクラスターの脱離しきい温度と一致している。すなわ ち, SAM の crystal-rotator 相転移がナノクラスターを単 分子膜内部から放出する（脱離させる）過程に対応して いると結論できる ${ }^{8)}$ 。つまり，単分子膜内に打ち込まれ たサンドイッチ錯体は, SAMの 2 次元融解によって脱 離することがわかる。

\section{5.おわりに}

以上のように，気相反応場から生み出されたナノクラ スターを, 実際のナノ構造機能材料へと展開していくた めの方策と最近の研究成果について紹介した。ソフトラ ンディング技術によって，気相ナノクラスターをサイズ 選別して壊すことなく基板表面上へ大量集積することが 可能となり, ナノクラスターの材料化へ大きく前進し た。実際，この SAM を用いるソフトランディング法に よって, クラスター磁石と位置付けられる $\mathrm{V}_{2}\left(\mathrm{C}_{6} \mathrm{H}_{6}\right)_{3}$ の単離に成功している9)。さらに，ナノクラスターを蒸 着する基板表面を自己組織化単分子膜のような周期秩序 をもった集合体で修飾しておくと，基板表面上における ナノクラスターの配向を制御できることが明らかとなっ た。今後，基板表面上でのナノクラスターの吸着状態を 化学修飾によって精密に制御する方法の拡充を進めると ともに ${ }^{10)}$ ，ナノ集合体修飾基板の電子物性を評価するこ とと併せることによって，気相生成されたナノクラス夕 一が磁気素子や光応答素子などの新機能性ナノ構造体材 料として供給されるものと確信している。

\section{謝 辞}

本稿の内容は, 三井正明博士 (現, 静岡大学), 長岡 修平博士, 松本剛志君, 池本佳織さんらとの実験研究に よるもので，この一部は，科学研究費補助金基盤研究 （A）ならびに特定領域研究「実在系の分子理論」の研 究助成を受けて行われた。

\section{文献}

1) A. Nakajima and K. Kaya : J. Phys. Chem. A 104, 176 (2000).

2) 菅野 暁, 近藤 保, 茅 幸二/編 : “新しいクラス夕 一の科学” (講談社, 2002).

3) P. Weis, P.R. Kemper and M.T. Bowers : J. Phys. Chem. A 101, 8207 (1997).

4) K. Miyajima, K. Muraoka, M. Hashimoto, T. Yasuike, S. Yabushita, A. Nakajima and K. Kaya : J. Phys. Chem. A 106, 10777 (2002).

5) K. Miyajima, S. Yabushita, M.B. Knickelbein and A. Nakajima : J. Am. Chem. Soc. 129, 8473 (2007).

6) S. Nagaoka, T. Matsumoto, E. Okada, M. Mitsui and A. Nakajima: J. Phys. Chem. B 110, 16008 (2006).

7) S. Nagaoka, K. Ikemoto, T. Matsumoto, M. Mitsui and A. Nakajima: J. Phys. Chem. C 112, 15824 (2008).

8) S. Nagaoka, K. Ikemoto, T. Matsumoto, M. Mitsui and A. Nakajima : J. Phys. Chem. C 112, 6891 (2008).

9) S. Nagaoka, T. Matsumoto, K. Ikemoto, M. Mitsui and A. Nakajima : J. Am. Chem. Soc. 129, 1528 (2007).

10) K. Ikemoto, S. Nagaoka, T. Matsumoto, M. Mitsui and A. Nakajima : J. Phys. Chem. C 113, 4476 (2009). 